\title{
Production of high quality castile soap from high rancid olive oil
}

\author{
By Adel Y. Girgis *
}

Agricultural Res. Centre, Food Tech. Res. Institute, Oils and Fats Res. Dept., 9 El-Gamaa St., Post no. 12619, Giza, Egypt.

\section{RESUMEN}

Producción de jabón tipo "Castilla" de alta calidad a partir de aceite de oliva de alta rancidez.

Aceite de oliva no comestible, caracterizado por su alta acidez e índice de peróxido así como de su elevada coloración y sabor desagradable se utilizó para la producción de jabón fino tipo "Castilla" (muestra de jabón n ${ }^{\circ} 1$ ). Otro aceite de oliva semifino se empleo para la fabricación de jabón estándar tipo "Castilla". Los resultados mostraron que el olor desagradable había desaparecido de la muestra de jabón $n^{\circ} 1$ mientras que el de la muestra $n^{\circ} 2$ mantenía un ligero olor a aceite. No se apreciaron diferencias notables entre las dos muestras en cuanto a las propiedades físicas $n$ químicas (apariencia, suavidad en la superficie, erosión al lavar las manos, humedad, ácidos grasos totales, alcalinidad y contenido en sal. En cambio el color del jabón $n^{\circ} 1$ fue verde oscuro y el del jabón estándar fue amarillo pálido a blanco. El almacenamiento del jabón estándar fue amarillo pálido a blanco. El almacenamiento del jabón a temperatura ambiente en estantería durante 6 meses dio lugar a algunos cambios en sus propiedades en sus propiedades químicas y sus propiedades físicas mejoraron volviéndose sus estructuras más firmes, aumentó el volumen de espuma producido y disminuyó a razón de erosión en el lavado de manos. El color en la muestra $n$ 1 no mejoró y siguió siendo verde oscuro. De acuerdo con este estudio es, pues, recomendable el uso de aceite de oliva no comestible como una fuente no usual de ácidos grasos para la producción de jabón fino tipo "Castilla", lo que reduce sus costes de producción.

PALABRAS-CLAVE: Aceite de oliva comestible - Aceite de oliva de alta rancidez - - Almacenamiento - Jabón de tocador tipo "Castilla"- Propiedades físicas -- Propiedades químicas.

\section{SUMMARY}

Production of high quality castile soap from high rancid olive oil.

Non-edible olive oil, characterized by high acid and peroxide values as well as deep in color and unpleasant odor, was used to values as well as deep in color and unpleasant odor, was used to produce a fine castile soap (soap sample no. 1). Semi-fine virgin olive oil was also used to produce the standard castile soap (soap sample no. 2). The obtained results illustrated that the unpleasan odor was disappeared in soap no. 1 compared to the standard soap (weakly like oil). Also, there were remarkable that no high differences were observed in all physical and chemical properties (appearance, smooth surface, erosion from hand-washing, consistency, moisture content, total fatty acids, free alkali and salt content) in the two fresh soap samples. Whilst, the color in soap sample no. 1 was fuscous green color compared to the standard soap (which was white to pale yellow). Soap samples were stored on a shelf at room temperature for 6 months showed some changes in their chemical properties. On the other hand, physical properties of the above two samples were improved after the storage period ( 6 months) where their structures became very firm with high lather volume and rates of their erosions from hand-washing were retrenched except, the color in soap sample no. 1 was not improved which was dark green color.
Therefore, the present study recommend to use non-edible live oil as unusually fatty material to produce a fine castile soap (high smooth surface, fairly lather and high glossy appearance) as an alternative to edible olive oil (which is very expensive) and also to reduce the cost of castile soap manufacturing.

KEY-WORDS: Castile soap -- Chemical properties Edible olive oil -- High rancid olive oil --Physical properties - Storage.

\section{INTRODUCTION}

Soaps are derived from natural oils or fats by reacting them with caustic soda in the process known as saponification [Head et al., (1995) and Hui (1996)]. Martin (1950 \& 1951) referred that olive oil saponifies readily with lyes of very different densities, yielding a greenish-colored soap called castile which gives a thin, slimy, but abundant lather peculiar to all soaps containing much oleate.

Norman (1981) asserted that mono-unsaturated fatty acid (oleic acid) is required for gentle products such as, e.g., "Castile" baby soaps. Micheal (1996) mentioned that castile soap is made from olive oil. Martin (1951) referred that the soap derived from olive oil is an ideal one for toilet purposes, but it is very expensive. S.B.P. (1987) cited that olive oil (soft oil) gives soap that has the desired ready solubility in water. Also, S.B.P. (1987) marked that the olive oil soap produces profuse, but thin and greasy foam.

Ensminger et al., (1995), Hui (1996) and Micheal (1996) pointed out that castile soap is reputed to be less irritating to the skin than ordinary toilet soaps and hence it is used as soap for infants. In Egypt, about $80 \%$ of total production of olive fruit $(287000$ tons) (The Egyptian Agriculture Ministry, 2001) is consumed as table olive while the residual $(20 \%)$ is used in oil production. On the other hand, the oil in most of the olive cake (It is obtained after fresh fruit olive pressing step) is not extracted in Egypt, which the cake utilized as either fuel or fertilization of earth. Subsequently, the price of olive oil in Egypt has sharply risen. Thereon, the present production volume of castile soap is very low.

The main object of the present work was to use the high rancid olive oil (non-edible oil) as a substitute for fatty material (edible olive oil) to 
produce a fine castile soap. In addition, the attention was focused on produce castile soap from cheap source.

\section{MATERIALS AND METHODS}

\subsection{Materials}

- Semi - fine virgin olive oil was purchased from Atals Company for Edible Oils, Wadi El-Natroun, Behera Governorate, Egypt.

- Rancid olive oil was brought from Cairo local market, Egypt.

- Sodium hydroxide was obtained from El --Gomhoria Company for Pharmaceutical, Cairo, Egypt.

- Sodium chloride was supplied from El -- Nasr Salinas Company, Alexandria Governorate, Egypt.

\subsection{Methods}

Determination of physical and chemical properties of olive oils

Moisture and volatile matter (\%), acidity (\%) as oleic acid, peroxide value (Meq. peroxide / kg oil), saponification value, iodine number as hanus, titer number ${ }^{\circ} \mathrm{C}$, unsaponifiable matter (\%) and impurities $(\%)$ in the olive oil samples were determined according to the procedures described in the A. O. C. S. (1997), while I.N.S. factor was calculated (as a difference between saponification value and iodine number) according the method proposed by Ahmed (1981), as well as, the color was measured by Lovibond tintometer, model E, using 5.25 inch cell following the method found in the A. O. C. S. (1993). Conjugated trienes (absorbance at $270 \mathrm{~nm}$ ) in the oil samples were measured according to the method reported in the FAO/WHO (1970) using U.V. Spectrophotometer model U.V.--VIS., 120- 02.While the odor of oil sample was sensory evaluated according to the method described by Kiritsakis (1991).

\section{Methylation of the fatty materials}

The methyl esters of fatty materials (non-edible and edible olive oils) were prepared [using benzene: methanol: concentrated sulfuric acid (10: 86: 4)] and methylation was carried out by heating at $90 \pm 1^{\circ} \mathrm{C}$ for one hour according to the method described by Ludy et al., (1968).

\section{Identification of fatty acid methyl esters}

The fatty acid methyl esters of the two olive oil samples were separated and quantitatively determined using Gas - liquid chromatograph apparatus (Pye-Unicam Model 4550) as the method reported by Zygadlo et al., (1994). Peaks' area was measured using spectrophysic integrator.

\section{Purification of non-edible olive oil}

Non-edible olive oil was washed with $3 \% \mathrm{NaCl}$ from oil weight $\left(10 \%\right.$ hot brine at $\left.70^{\circ} \mathrm{C}\right)$ with stirring at $60 \mathrm{rpm}$ for $60 \mathrm{~min}$ then settled for $6 \mathrm{hrs}$ to separate any impurities found in the olive oil. The non-purified and purified olive oil samples were analyzed for their acidity (\%) as oleic acid, impurities (\%) and color (using Lovibond tintometer model E) according to the methods described in the A. O. C. S. (1997). While the odor was sensory evaluated according to the method descried by Kiritsakis (1991).

\section{Manufacturing of castile soap}

The actuality method used to saponify the olive oils in this study can be explained in detail as follows: One $\mathrm{kg}$ from non-edible (after its purification) and edible olive oils was separately saponified with caustic soda using a hot plate $\left(90 \pm 5^{\circ} \mathrm{C}\right)$. The contents of caustic soda used for full saponification were 13.2 and $13.4 \%$ (from weight of oil) for non-edible and edible olive oils, respectively, with 3.0 $\%$ excess of caustic soda. The concentration used of caustic soda solution to saponify both non-edible and edible olive oils were 33 and $37^{\circ} \mathrm{Be}$ (Bume) or ( 8.2 and $9.5 \mathrm{~mol} /$ litre), respectively. The hot caustic soda $\left(90 \pm 5^{\circ} \mathrm{C}\right)$ was separately added slowly to the two heated olive oils $\left(90 \pm 5{ }^{\circ} \mathrm{C}\right)$ until complete saponification has taken place, followed by the addition of $5-10 \%$ hot water $\left(90 \pm 5^{\circ} \mathrm{C}\right)$ to remove the excess of caustic soda from the soap paste. After that, about $6.0 \%$ sodium chloride $(10 \%$ hot brine at $90 \pm 5^{\circ} \mathrm{C}$ ) was gradually added over the surface of soap during its boiling to separate spent lye in the bottom, while the saponified mass was floated on the surface. Spent lye was extracted by siphoning. The soap paste was washed again with $5-10 \%$ hot water $\left(90 \pm 5{ }^{\circ} \mathrm{C}\right)$ to reduce the excess of sodium hydroxide and sodium chloride with any impurities found in the soap paste. The homogeneity of soap was tested during and after the complete saponification process using the knife test, the fingers method and the total electrolyte (free alkali as $\mathrm{NaOH} \%$ and salt content as $\mathrm{NaCl} \%$ ). The soap paste was poured onto a wooden frame and left at room temperature for harding. The block of soap was cut into small soap bars (about150g) then, stored on a shelf at room temperature.

Quantities of the resultant soap samples from two olive oils are shown in Table I. Soap sample no. 2 was the standard soap. The produced soap samples were analyzed for their chemical properties at zero time 
Table I

Composition (\%, w/w) and quantities of castile soap samples made from non- edible and edible olive oils

\begin{tabular}{lcc}
\hline \multicolumn{1}{c}{ Soap made from } & $\begin{array}{c}\text { The total amount of sodium } \\
\text { hydroxide (\%) }\end{array}$ & $\begin{array}{c}\text { Quantities of the produced } \\
\text { soap (g) }\end{array}$ \\
\hline $100 \%$ Non-edible olive oil (sample no. 1) & 16.2 & 1470 \\
$100 \%$ Edible olive oil ( sample no. 2) & 16.4 & 1480 \\
\hline
\end{tabular}

Table II

Changes occurred in some properties of rancid olive oil after its washing with $3 \%$ sodium chloride (as $10 \%$ hot brine). Some physical and chemical properties of the olive oil samples used in this study

\begin{tabular}{|c|c|c|c|c|c|c|c|c|c|c|c|c|c|c|}
\hline \multirow[b]{2}{*}{ Giveoil } & \multirow{2}{*}{$\begin{array}{c}\text { Moistureand } \\
\text { volatilimanter } \\
(\%)\end{array}$} & \multirow{2}{*}{$\begin{array}{l}\text { Adidiy (9g as } \\
\text { olic aadd }\end{array}$} & \multirow{2}{*}{$\begin{array}{c}\text { Peroxide } \\
\text { value(meq } \\
\text { peroxide } k g \\
\text { oil) }\end{array}$} & \multirow{2}{*}{$\begin{array}{c}\text { Saporification } \\
\text { value }\end{array}$} & \multirow{2}{*}{$\begin{array}{c}\text { looine } \\
\text { number }\end{array}$} & \multirow{2}{*}{$\begin{array}{l}\text { Titer number } \\
\left.{ }^{\circ} \mathrm{C}\right)\end{array}$} & \multirow{2}{*}{$\begin{array}{l}\text { Unsaponifiable } \\
\text { matter } \\
(\%)\end{array}$} & \multirow{2}{*}{$\begin{array}{c}\text { Impunities } \\
(\%)\end{array}$} & \multirow{2}{*}{$\begin{array}{l}\text { INS } \\
\text { factor }\end{array}$} & \multicolumn{3}{|c|}{$\begin{array}{l}\text { Colo Loibond } \\
\text { (5.25inch oell) }\end{array}$} & \multirow{2}{*}{$\begin{array}{l}\text { Total } \\
\text { odar }\end{array}$} & \multirow{2}{*}{ 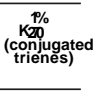 } \\
\hline & & & & & & & & & & $Y$ & $\mathbf{R}$ & B & & \\
\hline 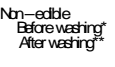 & 1.1 & $\begin{array}{l}60.1 \\
4.2 .2\end{array}$ & 382 & $18 \overline{2}$ & 793 & 30.1 & 1.1 & $\begin{array}{l}1.2 \\
0.4\end{array}$ & $10 \overline{.} .9$ & $\underset{35}{35}$ & $\begin{array}{l}9.0 \\
68\end{array}$ & $\begin{array}{l}200 \\
150\end{array}$ & 253 & $0 ఱ 8$ \\
\hline Edide & 0.08 & 22 & 151 & 189.3 & 821 & 29.6 & 0.72 & 0.08 & 107.2 & 36 & 4.1 & 29 & 106 & 03 \\
\hline
\end{tabular}

Notes: *Odor: rancidity; **Odor: slight rancidity

and at different periods during the storage period (6 months), while the physical characteristics were analyzed only at zero time and at the end of storage time (6 months).

Determination of some chemical properties of the manufactured soap samples

Moisture content (\%), free alkali ( $\mathrm{Na} \mathrm{OH} \%)$, salt $(\mathrm{NaCl} \%)$, total fatty acids (\%), free oil (\%), unsaponifiable matter (\%) and unsaponified matter (\%) of the obtained soap samples were determined according to the procedures described by The Egyptian Standard Specifications (1992) and the A. O. C. S. (1997).

\section{Determination of some physical properties of the} resultant soap samples

Color of the fatty acids (using Lovibond tintometer in 5.25 inch cell) and titer number ${ }^{\circ} \mathrm{C}$ (T. N.) of the derived soap samples were measured according to the methods found in the A. O. C. S. (1997).

The consistency and appearance of the soap samples were evaluated according to the methods reported by Martin (1951), while hand lather preference and erosion from hand-washing of the studied soap samples were estimated following the methods outlined by Ginn et al., (1968) and Gupta (1991). All analyses were performed in duplicate and the mean values are presented in the text.

\section{RESULTS AND DISCUSSION}

\subsection{Effect of washing step with $3 \% \mathrm{NaCl}(10 \%$ hot brine) on some properties of non-edible olive oil}

Pre-preparation of the fats and oils will have a bearing on the color and odor of the finished base soap (Willcox, 1993). Data tabulated in Table II show some changes occurred in characteristics of the rancid olive oil (non-edible) after the treatment with hot brine $\left(70^{\circ} \mathrm{C}\right)$. From these results, it appears that the acidity of non-edible olive oil decreased after the treatment from 60.1 to $43.2 \%$. This decrement may be due to the hot brine made to isolate (separate) part of low molecular weight free fatty acids from the rancid olive oil. Also, the data show that there was a high reduction in the total color of non-edible olive oil sample after the washing step. This development in the color is nearly in as much as the hot brine removed part of the pigment contents (by sedimentation).

Also, the impurities content reduced in the treated oil. This declinement is possibly related to the effect of hot brine on the proteinaceaus solids which occurred hydration in the impurities resulting their swelling up and increasing in their density. Regarding, the odor of non-edible olive oil sample was developed (see Table II). This improvement can be due to the brine removed most of the rancidity components (such as free fatty acids, aldehydes and ketons). All the previous results are somewhat in 
harmony with those found by Martin (1951) and Hui (1996), who reported that most impurities (some of pigments, free fatty acids, insoluble materials and hydroperoxide components) are removed by sodium chloride solution.

\subsection{Some physical and chemical properties of olive oil samples}

Many factors affect the quality of olive, such as collection, handling and, storage of the fruits, the extraction process and the storage of olive oil (Kiritsakis 1991). The characteristics of the two olive oil samples (washed and edible olive oils) are shown in Table II. From the results, it can be noticed that the level of moisture and volatile matter of non-edible and edible olive oil samples were 1.1 and $0.08 \%$, respectively. The value for non-edible was higher than those limited by IOOC (1984) and The Egyptian Standard Specifications (1993) (less than $0.2 \%$ for virgin olive oil). Therefrom, the edible olive oil is in the range $(0.08 \%)$. The acidity of industrial olive oil has higher than $3.3 \%$ (Kiritsakis and Markakis 1991).

From the results, it is quite clear that the acidity of non-edible olive oil was very higher $(43.2 \%)$ than that found in the edible olive oil $(2.2 \%)$. This increment is nearly attributed to the high lipolytic action by lipase. Non-edible olive oil sample had the highest amount of peroxide value (38.2 meq. peroxide $/ \mathrm{kg}$ oil) compared with edible oil (15.1 meq. peroxide $/ \mathrm{kg}$ oil). This increase is bearable attributed to the formation of hydroperoxides. The peroxide value of edible olive oil is in the range with those cited by IOOC (1984), The Egyptian Standard Specifications (1993) and Hui (1996) (should be less than 20 meq. peroxide/kg oil). As for, the saponification value of non-edible olive oil, it was slightly lower (185.2) than that found in the edible olive oil (189.3). This difference may be owing to the high content of unsaponifiable matter in the non-edible olive oil $(1.1 \%)$ than in the edible olive oil $(0.72 \%)$.

The iodine values of the above olive oils were 79.3 and 82.1 , respectively. This slightly difference is possibly related to variation in the fatty acids composition in both olive oils. The values of saponification and iodine numbers for edible olive oil are within the range of those obtained by Considine and Considine (1982), S.B.P. (1987) and Kiritsakis (1991). The titer numbers for the two olive oils were nearly the same $\left(30.1\right.$ and $29.6{ }^{\circ} \mathrm{C}$ for non-edible and edible olive oils, respectively). These values are higher than those reported by Woollatt (1985) and S.B.P. (1987), which ranged from 17 to $26^{\circ} \mathrm{C}$. The variation in the titer values may be owing to the differences in fatty acids composition. The unsaponifiable matter of the non-edible and edible olive oils was 1.1 and $0.72 \%$, respectively. These findings are in line with those tallied by Kiritsakis (1991) and Hui (1996) (less than 1.5\% for virgin and refined olive oils). The impurities of non- edible olive oil was higher $(0.4 \%)$ than those reported by $100 \mathrm{C}$ (1984) and The Egyptian Standard Specifications (1993) (not more than $0.1 \%$ for virgin olive oil). Therefrom, the other olive oil was in the line $(0.08 \%)$. As seen in Table II, I.N.S. factor of non-edible olive oil was slightly lower (105.9) than that found (107.2) for edible olive oil. These data are like with those assigned (range from 105 - 112) by Considine and Considine (1982) and Hui (1996). As to, the color of non-edible olive oil was deeper color (total color $=$ 253) than in edible olive oil (total color $=105$ ). High difference was observed between the values of conjugated trienes (K270) for non-edible and edible olive oils. These variations are probably assigned to the highest content of carbonyl compounds (aldhydes and ketones) found in non-edible olive oil that in edible olive oil. On the other hand, IOOC (1984) and Kiritsakis (1991) mentioned that the value of the conjugated trienes must be less than 0.25 for ordinary olive oil.

The aforementioned findings indicate that the non-edible olive oil had high values of either acidity or peroxide and conjugated trienes (K270). Therefore, this oil is characterized by high rancidity that means no use in the edible purposes.

\subsection{Fatty acid composition (\%) of non-edible and edible olive oils}

The performance characteristics of a finished soap produced are affected by its fatty acids distribution (George, 1994). The percentage of fatty acids in non-edible and edible olive oil samples is shown in Table III. From these findings, it is quite clear that the two olive oil samples were rich in the mono-unsaturated fatty acid (oleic acid) which gave 58.2 and $60.7 \%$, respectively from the total fatty acids and following linoleic acid (14.3 and $15.3 \%$ respectively). Martin (1950) referred that olive oil consisted principally of olein -- the glyceride of oleic acid. The predominant saturated fatty acid in the above two olive oil samples was palmitic, which recorded 19.9 and $17.5 \%$ of the total fatty acids for non-edible and edible olive oils, respectively and followed by stearic acid which was 3.9 and $2.4 \%$, respectively from the total fatty acids. These values are different than those reported by Kirschenbauer (1960) and Considine and Considine (1982). They found that the percentage of oleic acid ranged from 69 to $85 \%$ and within range of $7--14 \%$ for palmitic acid, while linoleic acid ranged of $4-12 \%$. These variations are almost in view of the difference in varieties and climate conditions of the area and several other factors (Frezzotti and Manni, 1956) and (Christakis et al., 1980). 
Table III

Fatty acids composition (\%) of non-edible and edible olive oils

\begin{tabular}{|c|c|c|c|c|c|c|c|c|c|c|}
\hline & 14:0 & $C_{16: 0}$ & $C_{16: 1}$ & $\mathrm{C}_{18: 0}$ & $C_{18: 1}$ & ${ }^{C_{18: 2}} 2$ & $\begin{array}{l}C \\
18: 3\end{array}$ & ${ }^{C}$ 20: 0 & $\begin{array}{c}\text { Total } \\
\text { unsaturated } \\
\text { fatty acids } \\
(\%)\end{array}$ & $\begin{array}{l}\text { Total saturated fatty } \\
\text { acids (\%) }\end{array}$ \\
\hline Non-edible & Trace & 19.9 & 2.1 & 3.9 & 58.2 & 14.3 & Trace & Trace & 74.6 & 23.8 \\
\hline Edible & Trace & 17.5 & 2.5 & 2.4 & 60.7 & 15.3 & Trace & 0.4 & 78.5 & 20.3 \\
\hline
\end{tabular}

On the contrary, the present findings are within the range obtained by Kiritsakis (1991) and Hui (1996). As for the total unsaturated fatty acids of non-edible olive oil sample was lower $(74.6 \%)$ than that found $(78.5 \%)$ in the edible olive oil sample and vice verse for total saturated fatty acids. These differences might be due to the partial oxidation of the double bonds of fatty acids for non-edible olive oil samples.

\subsection{Some physical and chemical properties of the fresh castile soap samples}

Qualitative assessments of some of the important properties of the castile soap samples derived from non-edible and edible olive oils are presented in Table IV, V, and VI . It is quite clear that no wide differences were observed in the values of either moisture or free alkali and total fatty acids (Table V) of the castile soap sample no.1 compared to the standard soap [castile soap no. 2]. The free alkali is similar with those reported by Martin (1951) and The Egyptian Standard Specifications [1992] (should not be arrived $0.3 \%$ ) while, the moisture and total fatty acids were higher than that recommended by The Egyptian Standard Specifications (1992) (must not be over than $22.0 \%$ for moisture and not less than $68.0 \%$ for total fatty acids). These differences are probably assigned to the used water content during the saponification process, which was high. Willcox (1993) stated that the total fatty acids in the neat soap were $65 \%$. The color of non-edible olive soap was the deepest [total color $=188$ ] that in the standard soap [total color $=83$ ] $($ Table VI). These variations are nearly in consideration of the used olive oil in castile soap no.1, which was deeper color than in the standard soap (light color). The semi-firm consistency of castile soap samples nos. 1 and 2 was in harmony with that found by Hui (1996), who mentioned that the high percentage of unsaturated fatty acids in oil produced soft and plastic consistency soap.

As to, the free oil of soap (Table IV) sample no.1 was higher $[0.67 \%]$ than that indicated $(<0.5 \%)$ by The Egyptian Standard Specifications (1992), while the free oil of soap no.2 was tantamount [0.48\%]. These changes are nearly in view of the content of unsaponifiable matter (Table II) in the used olive oil in soap no.1, which was high [1.1\%] compared to the standard soap [0.72\%]. Thus, the unsaponifiable matter of soap no. 1 was higher [0.59\%] than in the standard soap $(0.42 \%)$. The contents of unsaponified matter (Table IV) of the two soap samples (nos. 1 and 2) were somewhat equal $[0.08$ and $0.06 \%$, respectively]. These findings are similar with that recorded by The Egyptian Standard Specifications (1992) (should be less than $0.1 \%$ ). Titer numbers of soap (Table IV) sample nos.1 and 2 were somewhat equal [ 30.5 and $29.8^{\circ} \mathrm{C}$, respectively]. These values are agreement with that cited by the European standard for toilet soap, which assigned that titer number should be the range between $30-38^{\circ} \mathrm{C}$ until

Table IV

Some physical and chemical properties of the fresh castile soap samples (others can be seen as zero time in tables IV, $\mathrm{V}$ and VI)

\begin{tabular}{ccccc}
\hline Soap made from & $\begin{array}{c}\text { Free oil } \\
(\%)\end{array}$ & $\begin{array}{c}\text { Unsaponifi } \\
\text { able matter } \\
(\%)\end{array}$ & $\begin{array}{c}\text { Unsaponified matter } \\
(\%)\end{array}$ & $\begin{array}{c}\text { Titer number } \\
\left({ }^{\circ} \mathrm{C}\right)\end{array}$ \\
\hline $\begin{array}{c}\text { Non- edible } \\
\text { olive oil } \\
\text { [soap-no. 1] }\end{array}$ & 0.67 & 0.59 & 0.08 & $\mathbf{3 0 . 5}$ \\
$\begin{array}{c}\text { Edible olive oil } \\
\text { [soap-no. 2] }\end{array}$ & 0.48 & 0.42 & 0.06 & $\mathbf{2 9 . 8}$ \\
\hline
\end{tabular}


Table V

Changes occurred in some chemical properties of castile soap samples during the storage period (6 months) at room temperature

\begin{tabular}{|c|c|c|c|c|c|c|c|c|}
\hline \multirow{2}{*}{$\begin{array}{c}\text { Thestorageperiod } \\
\text { (doys) }\end{array}$} & \multicolumn{2}{|c|}{ Mosisture content $(\%)$} & \multicolumn{2}{|c|}{ Total fatty acids $(\%)$} & \multicolumn{2}{|c|}{ Freealkali(NaCH)(F) } & \multicolumn{2}{|c|}{ Salt content: $(N a C)(\%)$} \\
\hline & Non - ectibeolivedil & Eableolive al & Non - edole dived & Edibledived & Non - exibleodive di & Ecibledived & Non - edbleolived & Edoble olived \\
\hline Zeotime & 29.2 & 290 & 63.0 & 63.3 & 0.15 & 016 & 0.31 & 0.22 \\
\hline 15 & 27.8 & 27.8 & 64.2 & 64.6 & 0.14 & 0.15 & 0.32 & 0.23 \\
\hline 45 & 18.2 & 180 & 72.0 & 72.3 & 0.09 & 010 & 0.43 & 0.31 \\
\hline 90 & 12.0 & 11.4 & 782 & 78.7 & 0.06 & 007 & 0.58 & 0.42 \\
\hline 135 & 8.1 & 7.8 & 82.1 & 82.5 & 0.04 & 0.06 & 076 & 0.55 \\
\hline 180 & 79 & 7.6 & 82.3 & 82.8 & 0.04 & 0.04 & 077 & 0.56 \\
\hline
\end{tabular}

Note: The fatty materials of soap samples nos. 1 and 2 are found in table $\mathrm{I}$.

Table VI

Changes occurred in some physical properties of castile soap samples during the storage for 6 months at room temperature

\begin{tabular}{|c|c|c|c|c|c|c|c|c|c|c|c|c|c|c|c|c|}
\hline \multirow{3}{*}{ The strage time (dias) } & \multicolumn{6}{|c|}{ Color of fattly acids } & \multicolumn{2}{|c|}{ Total color } & \multicolumn{2}{|c|}{ Consistency } & \multicolumn{2}{|c|}{ Hand lather prefierence } & \multicolumn{2}{|c|}{$\begin{array}{l}\text { Erosion trom hand } \\
\text { washhing }\end{array}$} & \multicolumn{2}{|c|}{ Appearnce } \\
\hline & \multicolumn{3}{|c|}{ Non - ed lileollve dl } & \multicolumn{3}{|c|}{ Eduleollved } & \multirow{2}{*}{$\begin{array}{l}\text { Non - } \\
\text { endle } \\
\text { olve } \\
\text { d }\end{array}$} & \multirow{2}{*}{$\begin{array}{c}\text { Edile } \\
\text { dive } \\
d\end{array}$} & \multirow{2}{*}{$\begin{array}{l}\text { Non. } \\
\text { efoleolive } \\
\text { ol }\end{array}$} & \multirow{2}{*}{$\begin{array}{l}\text { Edble } \\
\text { olvedl }\end{array}$} & \multirow{2}{*}{$\begin{array}{l}\text { Nen. } \\
\text { exible } \\
\text { olved }\end{array}$} & \multirow{2}{*}{$\begin{array}{l}\text { Entble } \\
\text { ollve dl }\end{array}$} & \multirow{2}{*}{$\begin{array}{l}\text { Non. } \\
\text { athle } \\
\text { ollved }\end{array}$} & \multirow{2}{*}{$\begin{array}{l}\text { Enble } \\
\text { olved }\end{array}$} & \multirow{2}{*}{$\begin{array}{c}\text { Non - } \\
\text { colledive } \\
\text { d }\end{array}$} & \multirow{2}{*}{$\begin{array}{l}\text { Eodile } \\
\text { ollved }\end{array}$} \\
\hline & $Y$ & $\mathbf{R}$ & $\mathrm{B}$ & $Y$ & $\mathbf{R}$ & B & & & & & & & & & & \\
\hline Zerotme & 35 & 5.1 & 102 & 35 & 3.0 & 18 & 188 & 83 & seml-hard & Semthard & unate & unctle & unable & unable & $\begin{array}{l}\text { unappe- } \\
\text { arance }\end{array}$ & $\begin{array}{l}\text { unappe- } \\
\text { arance }\end{array}$ \\
\hline 15 & 35 & 5.1 & 102 & 35 & 3.1 & 2.0 & 188 & 86 & $\begin{array}{l}\text { close to } \\
\text { hard }\end{array}$ & $\begin{array}{l}\text { close to } \\
\text { hard }\end{array}$ & poor & poor & very high & very high & prie soft & palesoft \\
\hline 45 & 35 & 5.1 & 106 & 35 & 3.2 & 2.1 & 199 & $B 8$ & hard & hard & medium & medium & high & high & soft & soft \\
\hline 90 & 35 & 5.2 & 108 & 35 & 3.2 & 2.2 & 196 & 89 & $\begin{array}{l}\text { hardwth } \\
\text { smocth }\end{array}$ & $\begin{array}{l}\text { hardwth } \\
\text { smooth }\end{array}$ & fairly & fäly & fäly & fäilly & $\begin{array}{l}\text { sof with } \\
\text { glossy }\end{array}$ & $\begin{array}{l}\text { soft whth } \\
\text { glossy }\end{array}$ \\
\hline 135 & 35 & 5.2 & 109 & 35 & 3.3 & 2.4 & 197 & 2 & $\begin{array}{l}\text { very hard } \\
\text { wth } \\
\text { smoodh }\end{array}$ & $\begin{array}{l}\text { very hard } \\
\text { with } \\
\text { smooth }\end{array}$ & $\operatorname{good}$ & good & $\begin{array}{l}\text { fatly to } \\
\text { medium }\end{array}$ & $\begin{array}{l}\text { fiarly to } \\
\text { medum }\end{array}$ & $\begin{array}{l}\text { very solt } \\
\text { with glossy }\end{array}$ & $\begin{array}{l}\text { very soft } \\
\text { whth glossy }\end{array}$ \\
\hline 190 & 35 & 5.3 & 11.0 & 35 & 3.3 & 2.5 & 198 & 93 & $\begin{array}{l}\text { too very } \\
\text { hard with } \\
\text { smoch }\end{array}$ & $\begin{array}{l}\text { too very } \\
\text { hard wth } \\
\text { smooch }\end{array}$ & good & good & metium & medim & $\begin{array}{l}\text { pearly } \\
\text { luster }\end{array}$ & $\begin{array}{l}\text { pearly } \\
\text { luster }\end{array}$ \\
\hline
\end{tabular}

Note: The fatty materials of soap samples nos. 1 and 2 are found in table I.

produced hard consistency soap, which reported by Ainie et al.(1996). Subsequently, from the above data, it can be observed that physical and chemical properties of the castile soap sample no.1 was somewhat similar with that found in the standard soap [sample no.2], except the total color and free oil which were different. Therefore, castile soap sample no. 1 is fit for using after its hardness makeup.
3.5. Changes occurred in some chemical properties of castile soap samples during the storage period [6 months] at room temperature

Data in Table $\mathrm{V}$ appear some changes in chemical properties of the consequent soaps from different kinds of olive oils during their storage at room 
temperature for 6 months. From these findings, it can be noticed that the moisture contents of two castile soaps [nos. 1 and 2] decreased with increasing of the storage period. These decrements are contingent in respect that the free water in the soap samples was evaporated during the storage. On the contrary, total fatty acids of the aforementioned soap samples increased with increase of the storage time. These rises are possibly in consequence of the seducement in the moisture content of soap samples [nos. 1 and 2] during storage period. These findings are consentaneous with that reported by Girgis et al. (1998).

High decreases occurred in the free alkali of the above soap samples [nos. 1 and 2] were observed during the storage period [6 months]. These diminutions seem to be due to the continuous reactions between free oil and free alkali during the storage period of soap. Wide increases occurred in salt content $[\mathrm{NaCl}]$ of the previous castile soaps [nos. 1 and 2] were recorded during the storage [6 months]. These augments are almost related to the reductions occurred in the moisture content of soap samples during the storage. The above results are in line with that found by Girgis (1989). Also, from the above data, it is clear that no high differences occurred in the chemical properties of castile soap no. 1 [made from non-edible olive oil] compared to the control soap [made from edible olive oil] during the storage period. Therefore, it can be referred that chemical characteristics of castile soap samples nos. 1 and 2 are equal and they are suitable for using after their hard consistencies.

\subsection{Changes occurred in some physical properties of castile soap samples during the storage for 6 months at room temperature}

From findings in Table $\mathrm{VI}$, it is seen that all physical properties of two castile soap samples (nos. 1 and 2) were improved with increasing the period storage (6 months) wherefrom the consistency which became much firm with smooth surface as well as hand lather preference gave good and erosion from hand-washing recorded medium. Also, the appearance of the forerunner castile soap samples (nos. 1 and 2) was development from pale soft at 15 days from the storage to pearly luster after the ending of storage ( 6 months). On the other hand, the colors of sample nos. 1 and 2 were not improvement during the storage, which their colors became deep at the ending of storage, but the deep color intensity of the stored sample no.2 was slightly (total color = 93) than in another stored sample no.1 (total color = 198).

The semi-soft consistency of two castile soap samples (nos.1 and 2) agree with that cited by Hui (1996) who mentioned that the high percentage of unsaturated fatty acids in oil produced soft and plastic consistency soap. Also, these results for hand lather of the above soap samples [nos.1and2] are equal with those reported by several investigators [Jungermann (1979), Gunstone (1987) and S.B.P. (1987)] that tailed that soaps made from soft oils containing a higher percentage of unsaturated fatty acids give soaps that are quite good soluble in cold water but thin. The glossy and mildness of castile soap is due to either the absence of the medium molecular weight fatty acids or the high content of mono-unsaturated fatty acid (oleic acid) in the olive oil (Hui, 1996).

Also from data tabulated in the above table, it is evident that the physical properties of castile soap sample no.1 [made from non-edible olive oil] are somewhat close to that found in the standard soap [made from edible olive oil] at the end of storage from the points of structure, hand lather preference, erosion from hand-washing and appearance except the color of castile soap sample no.1 which was deeper than in castile soap sample no.2. Therefore, the non-edible olive oil gave a high quality castile soap comparison with the standard soap (made from edible olive oil). Thus, it can be recommended that two castile soap samples derived from either non-edible or edible olive oils must be used after 45 days from their manufacturing until give fine quality with regard to hard makeup and fairly hand lather preference with fairly to medium erosion from hand-washing as well as pearly luster appearance. At the end, it is clear that the properties of resultant soap sample from non-edible olive oil are very close with the soap made form edible olive oil.

Hence, from the results found in this study, it can be advised that non-edible olive oil can be used as an alternative to edible olive oil [which is very expensive] for production of high quality castile soap and also to reduce the production cost and the same time, to utilize from this waste in the manufacturing of castile soap.

\section{REFERENCES}

Ahmed, I. (1981).Use of palm stearin in soap. 1-9 Occasional paper no.2. Palm Oil Research Institute of Malaysia [PORIM], Selangor, Malaysia.

Ainie, K., Hamirin, K. and Peang-Kean, L. (1996). Chemical and physical characteristics of soap made from distilled fatty acids of palm oil and palm kernel oil. $J$. distilled fatty acids of palm oil and
Am. Oil Chem. Soc., 73, 105-108.

A.O.C.S. (1993, 1997). Official and Tentative Methods for the American Oil Chemist's Society. 6 and $7^{\text {th }}$ ed American Oil Chemist's Society, Champaign, U.S.A.

Christakis, G., Forduce, M.K. and Kurtz, C.S. (1980). The biological aspects of olive oil in Proceedings of the Third International Congress on the Biological Value of Olive Oil. Chanea, Greece.

Considine, D.M. and Considine, G.D. (1982). Foods and food production encyclopedia, p. 1373.. Van Nostrand Reinhold Company, New York, U.S.A. 
Ensminger, A.H., Ensminger, M.E., Konlande, J.E. and Robson, J.R.K. (1995). The concise encyclopedia of foods and nutrition, p. 797, 801.. C.R.C. Press, London.

FAO/WHO [Food and Agriculture Organization/World Health Organization] (1970). Recommend international and standard for olive oil. Codex Alimentarius Commission CAC/RS 33, Roma, Italy.

Frezzotti, G. and Manni, M. (1956). Olive oil processing in rural mills. Agricultural development, FAO, Roma, paper no. 58.

George, E.D. (1994). Fatty acid distribution of fats, oils and soaps by high-performance-liquid chromatography without derivatization. J. Am. Oil Chem. Soc., 71, 789-791.

Ginn, M.E., Steinhauer, R.C., Liebman, D. and Eungermann, E. (1968). Effect of tallow-coconut fatty acid ratios on properties of bar soaps. J.Am. Oil Chem. Soc., 45, 666-669.

Girgis, A. Y. (1989). Studies on the manufacture of soap . P 53,55 . M . Sc. Thesis, Faculty of Agric., Zagazig Univ., Egypt.

Girgis, A.Y., Abd El-Aziz, N.M. and Abd El-Salam, S.M. (1998). Physical and chemical characteristics of toilet soap made from apricot kernel oil and palm stearin. grasas y Aceites, 49, 434-439.

Gunstone, F.D. (1987). Palm oil, p.96. Published for the Society of Chemical Industry by John Wiley and Sons, New York, U.S.A.

Gupta, S. (1991). Chemistry, chemical and physical properties and raw materials in Soap technology for the 1990's. Chapter 2, p. 48, 70. L. Spitz (Ed.). Am. Oil Chem. Soc., U.S.A.

Head, S.W. Swetman, A.A and Hammonds T.W. (1995). Small-scale vegetable oil extraction, p.80. NRI [Natural Resources Institute], Kent, United Kingdom.

Hui, Y.H. (1996). Bailey's industrial oil and fat products, p.340. A Wiley Interscience Publication, John Wiley and Sons Inc., New York, U.S.A.

IOOC [International Olive Oil Council] (1984). International trade standard applying to olive oil and olive residue oils. COI/T.15/NC no.1, Madrid, Spain.

Jungermann, E. (1979). Soap. In: Bailey's industrial oil and fat products. $4^{\text {th }}$ Edition, Vol. 5, Chapter 8, p. 575. D. Swern (Ed.). A Willey Interscience Publication, New York, U.S.A.

Kirschenbauer, H.G. (1960). Fats and oils. An outline of their chemistry and technology, p. 172, 175. Reinhold publishing, New York, U.S.A.
Kiritsakis, A.K. (1991). Olive oil, p. 128, 136, 144. Am. Oil Chem. Soc., Illinois, U.S.A.

Kiritsakis, A. and Markakis, P. (1991). Olive oil analysis. In: Essential oils and waxes, Chapter 1, p. 1-20. H.F Linkens and J.F. Jackson (Eds.). Springer-Verlarg, Berlin.

Ludy, J.E., Barford, R.A., Bard, S.F. and Magidman, D. (1968). A rapid and quantitative procedure for the preparation of methyl esters of butter oil and other fats. J. Am. Oil Chem. Soc., 45, 549-552.

Martin, G. (1950). The modern soap and detergent industry, Vol. 1, p. 32, 35. The Tech. Press Ltd. London. Martin, G. (1951). The modern soap and detergent industry, Vol. 2, p.9, 22, 32. The Tech. Press Ltd. London.

Micheal, R.B. (1996). Soap. In: Bailey's industrial oil and fat products, Vol. 5, Chapter 4, p. 161. Y.H. Hui (Ed.). John Wiley and Sons Inc., New York, U.S.A.

Norman, O.V.S. (1981). Current future fat-based raw materials for soap manufacture. J. Am. Oil Chem. Soc. 58, 155A-161A.

S.B.P. (Small Business Publications) (1987). Technology of laundry and toilet soaps, p. 12. Chemical Engineering Series no. 40, Delhi, India.

The Egyptian Agriculture Ministry (2001).The annual report of central department of agricultural economics. Cairo, Egypt.

The Egyptian Standard Specifications (1992). Egyptian Standard (1044/1992) for soap, Egyptian Organization for Standardization and Quality Control, Ministry of Industry, Cairo, Egypt.

The Egyptian Standard Specifications (1993). Egyptian Standard (49/1993) for vegetable oils. Egyptian Organization for Standardization and Quality Control, Organization for Standardization
Ministry of Industry, Cairo, Egypt.

Willcox, M. (1993). Soap. In: Poucher's perfumes, cosmetics and soaps, Vol. 3, Chapter 15, p. 395, 396397. H.Butler. Champan and Hall, London.

Woollatt, E. (1985). The manufacture of soaps, other detergents and glycerine. $1^{\text {st }}$ ed. , p. 126. Ellis Howood Ltd., Chester, England.

Zygadlo, J.A., Morero, R.E., Abburra, R.E. and Guzman, C.A. (1994). Fatty acid composition in seed oils of some onagraceae. J. Am. Oil Chem. Soc., 71, 915-916.

Recibido: Noviembre 2001 Aceptado: Diciembre 2002 